\title{
PERAN PERPUSTAKAAN DALAM MENYEDIAKAN INFORMASI BAGI MASYARAKAT UMUM DI DINAS PERPUSTAKAAN DAN KEARSIPAN PROVINSI NUSA TENGGARA BARAT
}

\author{
Ridwan $^{1}$, Imam Tri Wahyudi ${ }^{2}$ \\ Jurusan Ilmu Perpustakaan, Fakultas Ilmu Sosial dan Ilmu Politik \\ Universitas Muhammadiyah Mataram \\ ridwanr320@gmail.com
}

\section{INFO ARTIKEL}

\section{Riwayat Artikel:}

Diterima:...-...-...

Disetujui:...-...-...

\section{Kata Kunci:}

Perpustakaan,

Pengolahan,

Layanan, Referensi,

\section{ABSTRAK}

Peneltian tentang peran perpustakaan dalam menyediakan informasi bagi masyarakat umum di Dinas Perpustakaan Dan Kearsipan Provinsi Nusa Tenggara Barat ini bertujuan untuk mengetahui peran Dinas Perpustakaan Dan Kearsipan Provinsi Nusa Tenggara Barat dalam upaya meningkatkan efisiensi dan efektifitas proses pencarian informasi bagi masyarakat umum. Manfaat dari penelitian ini diharapkan dapat dijadikan sebagai media pembelajaran dan informasi atau referensi bagi pembaca.

Metode yang digunakan dalam penulisan laporan ini adalah penelitian kualitatif deskriptif. Teknik pengumpulan data dilakukan dengan wawancara

,observasi dan penelitian kepustakaan. Teknik ini dilakukan dengan melakukan wawancara dengan 5 (lima) orang pustakawan dan dengan 2 (dua) orang pemustaka, mengamati kondisi lapangan pada saa itu dan menghimpun bahan pustaka guna membuktikan kesesuaian hasil analisa dan pendapat pakar. Penelitian ini dilakukan di Dinas Perpustakaan Dan Kearsipan Provinsi Nusa Tenggara Barat.

Hasil penelitian yang didapatkan menunjukkan bahwa kegiatan pelayanan yang dilakukan di Dinas Perpustakaan dan Kearsipan Provinsi Nusa Tenggara Barat sudah cukup baik karena mampu menyediakan bahan pustaka secara tepat dan akurat dalam rangka memenuhi kebutuhan informasi pemustaka.Salah satu pelayanan yang ada di Dinas Perpustakaan dan Kearsipan Provinsi Nusa Tenggara Barat adalah pelayanan referensi. Pelayanan referensi merupakan kegiatan yang berhubungan langsung dengan pemustaka yang berupa kegiatan tanya jawab dan menggunakan rujukan yang berhubungan dengan koleksi referensi. Salah satu upaya yang dapat dilakukan oleh Dinas Perpustakaan dan Kearsipan Provinsi Nusa Tenggara Barat untuk meningkatkan mutu layanannya. Meningkatkan mutu layanan dapat dilakukan dengan cara mengelola layanan perpustakaan yang representatif berdasarkan kebutuhan pemustaka. 


\section{A. PENDAHULUAN}

Masyarakat umum adalah masyarakat yang terdiri dari berbagai golongan masyarakat yang melakukan interaksi antar individu dengan adanya aturan yang berlaku yang gunanya untuk mengatur setiap individu dalam berinteraksi.Dalam berinteraksi masyarakat membutuhkan informasi untuk disampaikan dalam bentuk komunikasi.

Komunikasi adalah salah satu kebutuhan dalam masyarakat, karena dengan adanya komunikasi masyarakat dapat melakukan pertukaran informasi.Komunikasi yang baik dapat dilihat dari beberapa sisi seperti, adanya individu yang melakukan informasi, adanya informasi yang disampaikan dan tentu saja dengan adanya timbal balik atau respon dalam melakukan informasi.

Informasi adalah salah kebutuhan yang dibutuhkan yang dibutuhkan oleh masyarakat setelah makan. Informasi dapat didapatkan melalui banyak cara salah satunya adalah dengan berkunjung ke perpustakaan.

Menurut Sulistyo Basuki "Perpustakaan adalah sebuah ruangan atau Gedung yang digunakan untuk menyimpan buku dan terbitan lainnya yang biasanya disimpan menurut tata susunan tertentu yang digunakan pembaca bukan untuk dijual”. (Sulistyo Basuki: 1991).

Sedangkan menurut Sutarno NS "Perpustkaan mencakup suatu ruangan, bagian dari gedung atau bagunan atau gedung tersendiri yang berisi buku koleksi yang diatur dan disusun sedemikian rupa, sehingga mudah untuk dicari dan dipergunakan jiwa sewaktu-waktu diperlukan oleh pembaca." " . Sutarno NS (2009: 11).

Jadi penulis dapat menyimpulkan bahwa perpustakaan adalah sebuah tempat atau gedung yang di dalamnya berisi informasi-informasi berupa karya cetak maupun non cetak di atur dan di susun sedemikian rupa yang dibutuhkan oleh masyarakat guna menunjang kebutuhan informasi.
Perpustakaan memiliki peran yang sangat penting sebagai penyedia informasi dalam masyarakat.Perpustakaan menyediakan informasi yang dapat didapatkan secara gratis oleh masyarakat dengan syarat harus menjadi anggota perpustakaan. Hal itu dapat didapatkan dengan cara mengunjugi perpustakaan dan mencari bahan pustaka yang dibutuhkan oleh masyarakat. Berarti informasi yang ada dalam perpustakaan dapat didapatkan oleh masyarakat dari berbagai golongan masyarakat yang membutuhkan informasi.

\section{B. RUMUSAN MASALAH}

1. Bagaimana peran perpustakaan dalam menyediakan informasi bagi masyarakat umum?

2. Faktor-faktor apa sajakah yang menjadi penghambat dan pendukung dalam menyediakan informasi?

\section{LANDASA TEORI}

\section{Pengertian Perpustakaan}

Perpustakaan berasal dari kata "pustaka" yang berarti buku. Setelah mendapat awalan per dan akhiran an yang berarti kitab, kita primbom, atau kumpulan buku yan kemudian disebut koleksi bahan pustaka. Istiberlaku untuk perpustakaan yang masih bersifat tradisional atau perpustakaan konvesional . Sedangkan untuk perpustakaan modern, dengan paradigma baru ( kerangka berfikir atau model ilmu pengetahuan ), koleksi perpustakaan tidak hanya terbatas berbentuk buku, majalah, koran atau barang cetak lainya ( Sutarno : 2004 ).

Beberapa definisi perpustakaan menurut para ahli, Sulistyo Basuki mendefinisikan bahwa perpustakan adalah „,sebuah Gedung atau ruangan yang di gunakan untuk menyimpan buku dan terbitan lainya yang bisa di simpan menurut tata susunan untuk di gunakan pembaca, bukan untuk di jual belikan "'e'(Sulistyo Basuki: 1991) 
Sedangkan menurut Sutarno NS “Perpustakaan mencakup suatu ruangan, bagian dari gedung atau bagunan atau gedung tersendiri yang berisi buku koleksi yang diatur dan disusun sedemikian rupa, sehingga mudah untuk dicari dan dipergunakan jiwa sewaktu-waktu diperlukan oleh pembaca. (Sutarno NS 2009: 11).

Berdasarkan paparan diatas penulis dapat menyimpulkan bahwa perpustakaan merupakan salah satu layanan penyedia informasi yang memudahkan bagi para pemustaka guna memenuhi kebutuhan akan informasi.Perpustakaan merupakan salah satu pendidikan dan penelitian, keberaaaan perpustakaaan sangat straegis dalammemberikan pelayanan kepada masyarakat dan pemustaka.

Aktifitas utama dari perpustakaan adalah menghimpun informasi dalam berbagai bentuk atau format untuk pelestarian bahan pustaka dan sumber informasi sumber ilmu pengetahuan lainya. Tujuan perpustakaan adalah :

a. Menyediakan sarana atau tempat untuk menghimpun berbagai sumber informasi untuk di koleksi secara terus menerus, di olah dan di proses.

b. Sebagai sarana atau wahana untuk mlestarikan hasil budaya manusia (Ilmu pengetahuan teknologi dan budaya) melalui aktivitas pemeliharaan dan pengawetan koleksi.

c. Sebagai agen perubahan (Agent of changes) danagen kebudayaan serta pusat informasi dan sumber belajar mengenai masa lalu, masa sekarang dan masa yang akan datang. Selain itu juga bermaksud sebagai pusat penelitian , rekreasi dan aktifitas ilmiah lainya.

Jadi penulis dapat menimpulkan bahwa maksud dari tujuan berdirinya perpustakaan sebagai tempat untuk menyimpan, mengolah dan menyajikan informasi kepada pengguna pepustakaan atau pemustaka.

\section{Tujuan Perpustakaan}

Jenis - jenis perpustakaan di Indonesia menurut penyelenggaraanya dan tujuan di bedakan menjadi :

a. Perpustakaan Digital adalah perpustakaan yang berbasis tekhnologi digital atau mendapat bantuan computer dalam seluruh aktifitas perpustakaannya secara menyeluruh. Contohnya: Buku atau informasi dalam bentuk format electric book, piringan, pita mahnetik CD atau DVD rom.

b. Perpustakaan Nasional Replublik Indonesia yang selanjutnya di sebut perpustakaan nasional adalah Lembaga pemerintahan non departemen (LPND) yang melaksanakan tugas pemerintahan di bidang perpustakaan sesuai dengan peraturan perundangundangan yang berlaku, yang berkedudukan di ibu kota negara.

c. Perpustakaan kabupaten/kota adalah Lembaga teknis di bidang perpustakaan yang di selenggarakan oleh pemerintah daerah kabupaten / kota.

d. Perpustakaan umum adalah perpustakaan yang ada dibawah Lembaga yang menaunginya.

e. Perpustakaan khusus adalah perpustakaan yang diperuntukkan untk koleksi-koleksi tokoh terkenal.

Jadi berdasarkan paparan diatas penulis dapat menyimpulkan bahwa perpustakaan terdiri dari berbagai jenis dan memiliki pengertian, tujuan dan fungsi masing.

\section{Fungsi Perpustakaan}

Menurut Sulistyo Basuki (1991:27). Pada umumnya perpustakaan memiliki fungsi yaitu:

a. Sebagai sarana simpan karya manusia:

Perpustakaanberfungsi sebagai sarana simpan karya manusia khususnya karya cetak seperti buku, majalah dan sejenisnya.

b. Fungsi informasi:

Perpustakaan menyediakan berbagai nformasi meliputi bahan tercetak, terekam dan sejenisnya. 
c. Fungsi rekreasi:

Perpustakaan berfungsi sebagai rekreasi karena menyediakan buku- buku atau koleksi yang tidak menjemukan seperti buku cerita.

d. Fungsi pendidikan:

Perpustakaan menyediakan berbagai informasi yang dapat di gunakan sebagai bahan penunjang pendidikan dalam kegiatan proses belajar mengajar.

e. Fungsi kultural :

Perpustakaan sebagai tempat mendidik dan mengembangkan apresiasi budaya masyarakat.

f. Fungsi penelitian :

Perpustakaan menyediakan berbagai informasi yang dapat menunjang kegiatan penelitian.

Berdasarkan paparan diatas mpenulis dapat menyimpulkan bahwa perpustakaan memiliki beberapa fungsi yang tidak hanya sebagai tempat penyedia informasi tetapi perpustakaan juga dapat dijadikan sebagai tempat rekreasi dan hal yang bisa di gunakan sebagai sarana pendidikan dan mengembangkan apresiasi budaya masyarakat.

\section{Peran Perpustakaan}

Perpustakaan memiliki peran yang sangat penting guna menunjang kebutuhan informasi masyarakat.menurut Jawel Gardiner (Supriyadi: 1986: 78):

a. Menjadi media antara pemakai dengan koleksi sebagai sumber informasi pengetahuan.

b. Menjadi lembaga pengembangan minat dan budaya membaca serta pembangkit kesadaran pentingnya belajar sepanjang hayat.

c. Mengembangkan informasi antara pemakai dengan peyelenggarasehingga tercipta kolaborasi, sharing pengetahuan maupun karya ilmiah lainya.

d. Perpustakaan sebagai agen perubah, pembangunan dan kebudayaan manusia.

Sedangkan Menurut Qalyubi, dkk (2007), peran perpustakaan adalah: a. Sebagai sumber kegiatan belajar mengajar

b. Sebagai sarana pembantu dalam memeperluas pengetahun

c. Untuk mengembangkan minat baca dan budaya yang menuju kebiasaaan belajar mandiri

d. Untuk membantu anak dalam mengembangkan bakat, minat dan kegemaran

e. Untuk memperluas kesempatan belajar bagi pemustaka

f. Untuk membiasakan anak dalam mencari informasi di perpustakaan

Jadi penulis dapat menyimpulkan bahwa perpustakaan perpustakaan memiliki peran penting dalam kehidupan karena perpustakaan memiliki banyak informasi yang kita butuhkan .

\section{Pengertian Masyarakat Umum}

Menurut Comte dalam syani (2012: 31) "masyarakat umjum merupakan kelompok-kelompok mahluk hidup dengan realitas-realitas baru yang berkembang menurut hukum-hukumnya sendiri dengan berkembang menurut pola perkembanganya tersendiri.

Sedangkan menurut J.L Gillin dalam syani (2012:32)" masyarakat umum adalah sebuah kelompok manusia yang tersebar yang memiliki kebiasaan (habit), tradisi (tradition), sikap ( attitude) dan perasaan persatuan yang sama.

Dari pendapat-pendapat diatas dapat disimpulkan bahwa masyarakat umum adalah orang yang hidup Bersama dan menghasilkan kebudayaan, kebiasaan dan sikap persatuan.

\section{Pengetian Informasi}

Pendapat para ahli tentang informasi adalah sebagai berikut:

Menurut Anton M. Meliono (1990: 331) Informasi adalah data yang telah di proses untuk suatu tuuan tertentu. Tujuan tersebut adalah untuk menghasilkan sebuah keputusan . 
Menurut Jogianto HM (1999: 692), informasi dapat didefinisikan sebagai hasil dari pengolahan data dalam suatu bentuk yang lebih berguna dan lebih berarti bagi penerimanya yang menggabarkan suatu kejadian-kejaian (event) yang nyata (fact) yang digunakan untuki pengambilan keputusan.

Jadi penulis dapat menyimpulkan bahwa informasi adalah hasil dari pengolahan data menjadi bentuk ang lebih berguna bagi penerima dan bermanfaat dalam pengambilan keputusan.

\section{Sumber Informasi}

Pengetahuan dapat diperoleh melalui pencarian informasi yang bersifat menambah wawasan.Informasi tersebut sudah barang tentu diperoleh dari sumber informasi.Sumber informasi sendiri terbagi menjadi 2 yaitu sumber informasi primer dan sumber informasi sekunder.

Sumber informasi primer adalah sumber informasi yang memuat informasi asli. Informasi tersebut dituangkan dalam bentuk kata-kata, gambar, ataupun objek lainnya. Karena sumber informasi primer bersifat asli, biasanya informasi yang disajikan tidak mengalami penyuntingan, jadi informasi yang disajikan adalah informasi apa adanya. Apa yang disajikan oleh informasi primer tidak akan disertai dengan penafsiran, evaluasi, analisis, peringkasan, atau berbagai jenis komentar dari penulis atau pengarang yang menyajikan informasi tersebut. Informasi primer dapat terbagi menjadi 2, yaitu naskah dan materi/rekaman informasi.

Sumber informasi sekunder merupakan sumber informasi biasanya berisi tentang penafsiran, analisis, penjelasan, dan ulasan dari sumber informasi primer. Pada beberapa kasus, sumber informasi sekunder juga sering dijadikan sebagai sarana untuk mengajukan pertanyaan atau suatu pernyataan untuk mendukung atau tidak mendukung data dari sumber informasi primer.

\section{Jenis Informasi}

Terdapat beragam jenis informasi yang bisa dibedakan berdasarkan fungsinya.Sebagaimana kita ketahui, informasi merupakan salah satu dari komponen-komponen komunikasi Informasi menjadi bentuk pesan yang akan disampaikan dari pengirim pesan (sender) kepada penerima pesan (receiver). Oleh karenanya, terdapat beberapa macam jenis dari informasi yang akan ditransmisikan dalam proses komunikasi. Jenis ini sendiri dibedakan berdasarkan fungsi dari informasi itu sendiri.

Berikut adalah beberapa macam jenis dari informasi yang bisa kita identifikasi dalam suatu proses komunikasi. Ini akan sangat membantu terutama ketika kita akan menyiapkan strategi dalam komunikasi.

\section{a.Informasi Edukatif}

Informasi edukatif adalah segala macam jenis informasi yang bermanfaat dalam menambah pengetahuan seseorang.Jenis informasi ini biasanya ditemui pada dunia pendidikan seperti saat di sekolah atau perkuliahan.Bentuk yang lebih umum bisa ditemukn terutama pada informasi-informasi yang sifatnya tutorial atau mengajarkan sesuatu.

b. Informasi Persuasif

Bentuk informasi lain selanjutnya yaitu informasi persuasif. Informasi ini biasanya berupa ajakan untuk melakukan suatu hal tertentu.Selain itu, penerapannya juga bisa dilihat pada media-media iklan suatu produk yang umumnya juga memiliki sifat promotif.

c.Informasi Rekreatif

Informasi selanjutnya yaitu informasi dengan fungsi rekreatif.Rekreatif artinya 
menghibur.Jenis pesan yang disampaikan biasanya memiliki sifat yang ringan dan tidak terlalu sulit untuk dipahami.Sebagai contoh, bentuk candaan atau gurauan adalah bentuk yang paling umum yang sering ditemukan dalam penerapan komunikasi sehari-hari. Informasi yang ringan ini tentu sering digunakan dalam proses komunikasi rekreatif yang memang sifatnya hanya untuk menghibur saja.

\section{d. Informasi Berita}

Informasi berita lebih cenderung akan memaparkan berita dalam kontennya. Komunikasi biasanya akan berjalan dengan isi yang sangat informatif. Informasi ini juga bisa dituangkan ke dalam bentuk media cetak dan juga media lainnya.Informasi dalam bentuk berita ini sering kita jumpai penggunaannya dalam keseharian kita.Ini memberikan kemudahan-kemudahan tersendiri di dalam penerapan komunikasi.

\section{e.Informasi Demonstratif}

Informasi dengan sifat demoinstratif akan memberikan isi pesan yang berfungsi untuk menyelesaikan suatu pemecahan masalah melalui urut-urutan proses. Jenis informasi ini juga umum digunakan pada saat melakukan proses komunikasi yang sifatnya adalah tutorial. Hampir mirip dengan informasi edukatif, tetapi cakupannya lebih luas.

\section{f. Informasi Deskriptif}

Informasi deskriptif adalah bentuk informasi yang menggunakan penggambaran di dalamnya. Informasi ini biasanya akan menggambarkan ciri-ciri, keadaan, situasi atau bagaimana rupa suatu objek maupun tempat. Pada umumnya, informasi deskriptif akan memiliki penggambaran yang rinci di dalamnya.

\section{g. Informasi Naratif}

Berbeda dengan informasi yang sifatnya deskriptif, informasi naratif lebih cenderung akan banyak memberikan pemaparan melalui bentuk cerita. Karena sifatnya yang bercerita, maka di dalamnya akan ada alur, sudut pandang dan pihak-pihak yang terlibat di dalamnya.

h. Informasi Kronologis

Informasi dengan fungsi kronologis akan menjabarkan urut-urutan peristiwa. Ini mungkin akan sedikit mirip dengan informasi naratif, namun yang paling membedakan adalah bentuk alurnya yang selalu menggunakan alur maju. Umumnya informasi kronologis juga digambarkan dalam bentuk poin sehingga memudahkan untuk dipahami.

9. Faktor Pendukung Dan Penghambat Dalam Kegiatan Menyediakan Informasi.

Dalam kegiatan penyampaian informasi perpustakaan juga mengalami beberapa faktor yaitu faktor penghambat dan pendukung. Adapun beberapa faktor tersebut adalah:

a. Faktor pendukung

Adapun beberapa faktor pendukung antara lain:

1) Petugas perpustakaan

Petugas perpustakaan yang di maksud di sini adalah pustakawan.Pustakawan yang ada merupakan tenaga yang ahli dalam 
bidang perpustakaan.Hal tersebut tentu menjadi faktor pendukung dalam hal penyampaian informasi.

2) Koleksi

Koleksi yang ada di sana sudah lengkap karena sesuai dengan kebutuhan masyarakat umum. Koleksi perpustakaan yang di maksud di sini berupa koleksi cetak maupun non cetak.Dinas perpustakaan dan kearsipan provinsi nusa tenggara barat sudah memilliki kedua jenis koleksi tersebut.

3) Fasilitas

Fasilitas yang ada di Dinas Perpustakaan Dan Kearsipan Provinsi Nusa Tenggara Barat sudah terbilang bagus karena sudah memiliki fasilitas yang lengkap.

b. Faktor penghambat

Faktor penghambat dalam kegiatan penyediaan informasi antara lain:

1) Sumber Daya Manusia

Tenaga pustakawan yang ada di Dinas Perpustakaan Dan Kearsipan Provinsi Nusa Tenggara Barat masih banyak tenaga yang bukan seorang pustakawan asli melainkan hasil diklat.Hal ini merupakan salah satu faktor penghambat dalam penyampaian informasi di perpustakaan.

2) Fasilitas

Fasilitas yang ada si Dinas Perpustakaan dan Kearsipan Provinsi Nusa Tenggara Barat cukup karena memilik berbagai macam fasilitas yang sangat mempermudah pemustaka. Fasilitas yang dimiliki antara lain ruang tunggu saan antrian mengisi kartu anggota, computer di ruang internet yang memudahkan pemustaka yang tidak membawa laptop atau hp untuk internet, perpustakaan keliling dan proses pencarian bahan pustaka yang sudah terotomasi dan tentu saja sangat mempermudah pemustaka dalam pencaran informasi. Tetapi fasilitas yang ada masih terbatas karena masih terjadi antrian panjang saat kegiatan pengisian kartu anggota dan di tempat mencetak kartua nggota.

\section{HASIL DAN PEMBAHASAN}

1. Peran Perpustakaan Dalam Menyediakan Informasi Bagi Masyarakat Umum

Peran perpustakaan pada masyarakat sangatlah berpengaruh pada kebutuhan informasi guna menunjang kebutuhan aktivitasaktivitaskeseharian.Peran perpustakaan merupakan kedudukan, posisi, dan bagaimana perpustakaan memberikan pengaruh ke masyarakat di lingkungan perpustakaan.

Berdasarkan beberapa kajian literatur yang saya baca maka perpustakaan memiliki peran sebagai berikut:

a. Menjadi media antara pemakai dengan koleksi sebagai sumber informasi pengetahuan. Yang dimaksud di sini adalah perpustakaan dapat menjadi perantara antara pemustaka yang ingin mencari informasi melalui koleksi yang ada.

b. Menjadi lembaga pengembangan minat dan budaya membaca serta pembangkit kesadaran pentingnya belajar sepanjang hayat. Perpustakaan disini berperan mengembangkan budaya minat baca melalui promosi, sosialisasi kepada masyarakat dan menanamkan budaya minat baca kepada anak usia dini dengan cara melakukan kunjungan rutin di perpustakaan dan mengenalkan koleksi-koleksi yang ada.

c.Perpustakaan sebagai agen perubah, pembangunan dan kebudayaan manusia. Yang dimaksud disini adalah perpustakaan itu menjadi tempat rujukan dan sumber informasi bagi orang-orang yang memerlukannya,dan pembangunan di lakukan adalah untuk mencapai hal-hal yang lebih dan makin baik, dan semua itu merupakan bentuk dan wujud nyata suatu budaya bangsa dan umat manusia 
pada umumnya. Perubahan yang terjadi di masyarakat di mulai dari perpustakaan tentunya dilakukan oleh ilmuan dan peneliti dengan mengembangkan inspirasi, kreasi dan inovasi baru. Hal tersebut didasarkan pada pemikiran bahwa sesuatu yang berubah pada dasarnya diawali dengan penemuan dan perkembangan lmu pengetahuan.

Meskipun saat ini perpustakaan masih kurang mampu dimanfaatkan masyarakat bahkan dalam pendidikan juga masih belum optimal, namun perpustakaan sudah mampu melaksanakan peran dan tugas secara umum dengan baik. Tugas perpustakaan sebagai pusat informasi dan menyimpan segala ilmu pengetahuan dan memberikan layanan kepada pengguna ini telah dilaksanakan dengan sangat baik oleh perpustakaan, masyarakat dari berbagai kalangan pengguna yang harus mampu memanfaatkan berbagai kekayaan ilmu pengetahuan dan informasiyang tersimpan di perpustakaan sehingga dalam masyarakat perpustakaan memiliki fungsi yang penting.

Salah satu peran perpustakaan adalah menghimpun informasi meliputi kegiatan mencari, menyeleksi, dan mengisi perpustakaan dengan sumber informasi yang memadai dan lengkap baik dalam jumlah, jenis, maupun mutu yan disesuaikan dengan kebijakan organisasi.

Di Dinas Perpustakaan Dan Kearsipan Provisi Nusa Tenggara Barat terdapat berbagai informasi yang dapat dipinjam dan di maanfaatkan oleh masyarakat dalam bentuk koleksi.Koleksi umum terdiri dari kelas 000-90o ditambah fiksi dewasa maupun anak-anak, kemudian ada koleksi deposit yang merupakan buku- buku terbitan putra putri daerah NTB.Kemudian koleksi referensi buku yang dapat dipinjam oleh siapapun dari pelajar sampai masyarakat umum, kemudian ada ruang otomasi yang melayani pembuatan kartu anggota, perpanjangan kartu anggota dan layanan internet yang bisa di gunakan siapapun yang memiliki kartu anggota.

Untuk menguatkan pernyataan di atas penulis telah melakukan wawancara dengan beberapa narasumber dan hasil wawancara sebagai berikut:

Menurut ibu Dwi tentang bagaimana peran perpustakaan dalam menyediakan informasi terhadap masyarakat umum? Sebagai berikut:

"Penyediaan informasi di perpustakkan sudah banyak, jadi di sini sudah menyediakan berbagai macam koleksi yang bisa dipinjam oleh masyarakat, sehingga mereka bisa mengambil isi dan manfaat dari koleksinya.Jadi informasinya bisa didapatkan dari berbagai macam koleksi.Di sini ada koleksi secara umum dari kelas 000-90o ditambah fiksi dewasa dan fiksi anak. Lalu ada koleksi deposit buku buku terbitan putra putri NTB, sejarah Lombok, ketrampilan Budaya dan segala macam yang terkait tentang NTB ada di deposit. Ada juga koleksi referensi yang juga menyediakan informasi da nada juga layanan internet secara gratis di sini”.(Wawancara 21-05-2018).

Sedangkan menurut ibu Hermin tentang bagaimana peran perpustakaan dalam menyediakan informasi bagi masyarakat umum adalah.

"Perpustakaan berperan sangat penting dalam memenuhi kebutuhan masyarakat, masyarakat dapat memanfaatkan fasilitas berupa koleksi yang dapat di pinjam maupun tidak dapat di pinjam dan juga terdapat layanan internet guna menambah kemudahan bagi pemustaka untuk mendapatkan informasi". (Wawancara:21-05-2018).

Sedangkan Menurut ibu Kuni tentang bagaimana peranan perpustakaan dalam menyadiakan informasi bagi masyarakat umum adalah:

"Peranan perpustakaan dalam menyediakan informasi bagi masyarakat umum adalah dengan memberikan informasi yang sesuai dengan kebutuhanya melalui koleksikoleksi, pendidikan pemakai, dan memberikan informasi yang terbaru."(Wawancara: 21-052018).

Jadi menurut pernyataan di atas penulis dapat menyimpulkan bahwa peranan perpustakaan dalam menyediakan informasi bagi masyarakat umum sangatlah penting karena 
perpustakaan adalah sumber informasi yang sangat di butuhkan oleh masyarakat dan juga mampu memberikan informasi yang terbaru serta tidak hanya menyediakan koleksi dalam bentuk buku tapi juga menyediakan koleksi dalam bentuk digital.

\section{Faktor Penghambat Dan Pendukung Kegiatan} menyediakan informasi.

Dalam hal kinerja pustakawan terdapat beberapa faktor penghambat dan pendukung yang mengakibatkan penyampaian informasi yang diberikan oleh pustakawan merasa kurang bagi pemustaka. Faktor pendukung kinerja yang diberikan oleh pustakwan sangat berperanaktif bagi pemustaka yang membutuhkan membutuhkan informasi.

Sedangkan faktor penghambat kinerja pustakawan adalah factor yang dapat memperlambat kegiatan penyampaian informasi terhadapat para pemustaka yang membutuhkan informasi dan memberikan wawasan baru dalam hal menelusuri informasi.

\section{Faktor Pendukung Kegiatan Penyediaan} Informasi

Adapun beberapa faktor pendukung dalam kegiatan penyediaan informasi di Dinas Perpustakaan Dan Kearsipan Provinsi Nusa Tenggara Barat adalah:

a.Petugas Perpustakaan

Petugas perpustakaan yang dimaksud disini adalah pustakawan. pustakawan yang ada merupakan tenaga yang ahli dalam bidang perpustakaan. Hal tersebut tentu menjadi salah satu faktor pendukung dalam kegiatan pelayanan.

Untuk membuktikan bahwa pustakawan menjadi salah satu faktor pendukung dalam kegiatan penyediaan informasi penulis melakukan wawancara dengan beberapa pustakawan di Dinas Perpustakaan dan Arsip Provinsi Nusa Tenggara Barat dengan pertanyaan yang diajukan tentang bagaimana peran petugas perpustakaan dalam mendukung kegiatan penyampaian informasi perpustakaan adalah sebagai berikut:

Menurut ibu Hermin yang merupakan petugas dilayanan deposit dan pengembangan bahan pustaka tentang bagaimana peran petugas perpustakaan dalam mendukung kegiatan penyampaian informasi sebagai berikut:

Peran petugas perpustakaan dalam perpustakaan sangatlah penting terutama dalam kegiatan penyampaian nformasi, karena tanpa petugas perpustakaan tidak akan bisa berjalan karena petugas perpustakaan juga berperan sebagai pengelola perpustakaan. (wawancara: 21-052018).

Sedangkan menurut ibu made yang merupakan salah satu pustakawan memberikan pendapatnya sebagai berikut:

Petugas perpustakaan itu sangatlah penting, dan yang paling penting itu adalah petugas dibidang perpustakaan yang memang murni seorang pustakawan, dan disini masih banyak petugas perpustakaan yang memang berasal dari luar jurusan perpustakaan yang hanya mengikuti alih jalur atau diklat saja, tetapi kami masih tetap bisa mengatasi setiap masalah yang ada dengan baik-baik saja. (wawancara: 21-05-2018).

Pendapat selanjutnya juga dikemukakan oleh ibu Devi yang merupakan salah satu pustakawan dan pendapatnya sebagai berikut:

"Peran petugas perpustakaan dalam mendukung kegiatanan penyediaan informasi sangatlah besar, setiap petugas memiliki peran dan fungsi masing-masing contohnya kami disini terbagi menjadi beberapa layanan yang terdiri dari beberapa petugas yang menjalankan tugas masing-masing, dan peran petugas dalam mendukung penyediaan informasi sangatlah berperan aktif untuk mencapai kepuasan pengguna.( Wawancara: 21-05-2018). 
Dari pernyataan-pernyataan di atas dapat disimpulkan bahwa petugas perpustakaan berperan sangat penting dalam perpustakaan, hal itu dikarenakan tanpa petugas perpustakaan tidak akan berjalan dengan baik karen tidak adanya pengelolah.

Adapun menurut ibu aji salah satu pustakawan dilayanan anak menyatakan sebagai berikut :

"Peran koleksi perpustakaan yaitu salah satu bagian inti dalam mendirikan perpustakaan, karena koleksi dapat memenuhi kebutuhan pengguna akan informasi, koleksi ada bermacam-macam tergantung dari mana kita meninjaunya. Koleksi yang ada di perpustakan ini di sesuaikan dengan kebutuhan pemustakannya, ada juga yang disesuaikan dengan kurikulum pendidikan, kurikulum pendidikan yang di gunakan sekarang itu adalah K13, koleksi yang di adakan disesuakain dengan kurikulumnya mereka.( Wawancara : 21-052018).

Adapun menurut ibu Dwi salah satu pustakawan yang menyatakan sebagai berikut:

"Peran koleksi perpustakaan yaitu untuk mengembangkan pengetahuan dan meningkatkan minat baca masyarakat karena koleksi tersebut bebas digunakan oleh siapa saja Koleksi yang di dapatkan dalam perpustakaan tersebut melalui katalog penerbit dan ada yang langsung mencari ke toko buku. Koleksi yang dibutuhkan pemustaka adalah koleksi yang benar-benar akan di adakan, agar dapat meningkatkan minat baca masyarakat, dan kami disini khususnya layanan referensi tentu saja menyediakan koleksi rujukan dan hasil terbitan sendiri juga". Wawancara (21-052015).

Dari pernyataan di atas dapat disimpulkan bahwa koleksi sangat berperan penting dalam perpustakaan, hal itu dikarenakan koleksi yang ada dapat menjadi daya tarik pemustaka. Jadi perpustakaan harus mengetahui koleksi apa sajakah yang dibutuhkan pemustaka sebelum menyediakan bahan pustaka tersebut. b. Koleksi Perpustakaan

Koleksi yang ada di sudah lengkap karena sesuai dengan kebutuhan masyarakat umum. Koleksi perpustakaan yang dimaksud disini dapat berupa koleksi tercerak maupun non cetak. Dan koleksi yang dimiliki oleh Dinas Perpustakaan dan Kearsipan Provinsi Nusa Tenggara Barat sudah termasuk lengkap karena sudah memiliki kedua koleksi tersebut yaitu koleksi tercetak maupun non cetak.

Adapun wawancara yang penulis lakukan untuk menambah informasi dengan beberapa pustakawan antara lain, menurut Ibu Hermin salah satu pustakawan dibidang pengadaan, pengembangan dan pelestarian bahan pustaka menyatakan pendapatnya tentang bagaimana peran koleksi dalam menunjang kegiatan layanan sebagai berikut:

"Peran koleksi adalah salah satu media yang dapat digunakan untuk menambah wawasan, pengetahuan dan mendapatkan informasi secara gratis yang bisa di berikan oleh perpustakaan. Ada banyak koleksi yang ada di Dinas perpustakaan Dan Kerasipan Provinsi Nusa Tenggara Barat antara lain yaitu, ada karya cetak dan non cetak yg termasuk buku, ada koleksi referensi, terbitan berkala yang termasuk koran dan majalah yang diperlukan sebagai koleksi perpustakaan karena meliputi aspek kehidupan manusia. Agar koleksi tetap bisa dimanfaatkan Dinas perpustakaan Dan Kerasipan Provinsi Nusa Tenggara Barat memilih koleksi-koleksi sesuai dengan kebutuhan pemakai yang di layani. Selama ini yang dilakukan oleh perpustakaan daerah mataram itu adalah sebelum mengadakan koleksi terlebih dahulu melakukan survei pemakai bertujuan untuk mendapatkan informasi koleksi apa saja yang sangat di butuhkan, dari rujukan- rujukan itu dari informasi yang kita dapatkan dari pemustaka, dari situlah sumber kita untuk menyeleksi koleksi yang mau kita adakan. Dan disesuaikan juga dengan kurikulum pendidikan saat itu.(Wawancara: 21-05-2018). 
Adapun menurut ibu aji salah satu pustakawan dilayanan anak menyatakan sebagai berikut :

"Peran koleksi perpustakaan yaitu salah satu bagian inti dalam mendirikan perpustakaan, karena koleksi dapat memenuhi kebutuhan pengguna akan informasi, koleksi ada bermacam-macam tergantung dari mana kita meninjaunya. Koleksi yang ada di perpustakan ini di sesuaikan dengan kebutuhan pemustakannya, ada juga yang disesuaikan dengan kurikulum pendidikan, kurikulum pendidikan yang di gunakan sekarang itu adalah K13, koleksi yang di adakan disesuakain dengan kurikulumnya mereka.( Wawancara : 21-052018)

Adapun menurut ibu Dwi salah satu pustakawan yang menyatakan sebagai berikut:

"Peran koleksi perpustakaan yaitu untuk mengembangkan pengetahuan dan meningkatkan minat baca masyarakat karena koleksi tersebut bebas digunakan oleh siapa saja Koleksi yang di dapatkan dalam perpustakaan tersebut melalui katalog penerbit dan ada yang langsung mencari ke toko buku. Koleksi yang dibutuhkan pemustaka adalah koleksi yang benar-benar akan di adakan, agar dapat meningkatkan minat baca masyarakat, dan kami disini khususnya layanan referensi tentu saja menyediakan koleksi rujukan dan hasil terbitan sendiri juga". Wawancara (21-052015)

Dari pernyataan di atas dapat disimpulkan bahwa koleksi sangat berperan penting dalam perpustakaan, hal itu dikarenakan koleksi yang ada dapat menjadi daya tarik pemustaka. Jadi perpustakaan harus mengetahui koleksi apa sajakah yang dibutuhkan pemustaka sebelum menyediakan bahan pustaka tersebut.

\section{c. Fasilitas}

Fasilitas yang ada Di Dinas Perpustakaan Dan Kearsipan Provinsi NTB sudah terbilang bagus karena sudah meiliki fasilitas-fasilitas yang lengkap karena dilengkapi dengan gedung, koleksi, AC, meja, kursi, computer sudah terotomasi.
Pernyataan tersebut dapat di perkuat dengan hasil wawancara yang telah penulis lakukan sebagai berikut:

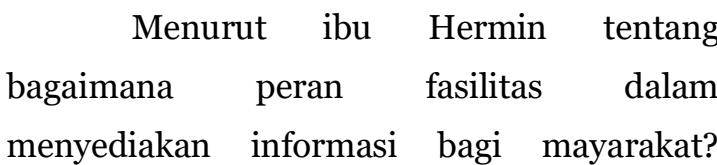

Sebagai berikut:

"Fasilitas tentu sangat berperan penting dalam rangka penyediaan informasi.Jadi kami disini sudah menggunakan fasilitas yang cukup bagus, fasilitas yang kami miliki disini ada fasilitas dalam ruangan yang berupa AC, modern karena kami disini sudah menggunakan sistem koleksi digital yang tentu saja mampu memberikan kemudahan akses koleksi bagi masyarakat semakin mudah.Setelah itu kami punya perpustakaan keliling jadi dengan adanya perpustakaan keliling kami dapat dengan mudah mengantar bahan koleksi ke pelosok-pelosok jadi semua orang dapat mendapatkan informasi yang merata. (Wawancara: 21-05-2018).

Sedangkan menurut ibu Made tentang bagaimana peran fasilitas dalam menyediakan informasi bagi masyarakat? Sebagai berikut:

"Salah satu faktor yang dapat memudahkan dalam kegiatan penyediaan informasi itu adalah fasillitas. Fasilitas itu tidak hanya apa yang ada didalam gedung ini tapi juga diluar gedung seperti bus keliling atau yang biasa dikenal dengan perpustakaan keliling, kenapa? karena perpustakaan keliling itu mampu membawa informasi sampai ke daerah-daerah yang sult dijangkau oleh gedung ini, dalam artian bahwa informasi itu tidak hanya dibutuhkan oleh orang yang ada di daerah mataram ini masyarakat diluar mataram pun harus mendapatkan informasi yang dibutuhkannya.( wawancara: 21-05-2018).

Untuk membuktikan bahwa fasilitas yang ada di Dinas Perpustakaan Dan Kearsipan Provinsi Nusa Tenggara Barat sudah mampu memberikan kepuasan bagi pemustaka, maka penulis melakukan 
wawancara dengan seorang pengunjung yang merupakan seorang mahasiswa. Dan hasl wawancaranya sebagai berikut:

\begin{abstract}
"Failitas yang ada disini sudah cukup baik, mungkin karena ini adalah perpustakaan yang sudah lama jadi mereka memiliki beribu-ribu koleksi yang tidak hanya koleksi cetak tapi koleksi non cetak juga ada, selain itu disini juga memudahkan pengunjung untuk mecari koleksi melalui aplikasi. Selain koleksi ada juga sarana dan prasarananya yang sudah memadai.( wawancara: 21-1512018).
\end{abstract}

Dari pernyataan diatas penulis dapat menyimpulkan bahwa peranan fasilitas sangatlah penting guna memaksimalkan kegiatan melayani informasi secara maksimal.

\section{Faktor Penghambat Kegiatan penyediaan} informasi.

Adapun faktor penghambat kegiatan penyediaan informasi adalah sebagai berikut :

\section{a.Sumber Daya Manusia}

Tenaga pustakawan yang ada di Dinas Perpustakaan Dan Kearsipan Provinsi Nusa Tenggara Barat masih banyak tenaga yang bukan seorang pustakawan asli melainkan dengan adanya diklat serta para pemustaka yang masih belum paham teknologi.

Hal itu diperkut dengan hasil wawancara yang penulis lakukan dengan beberapa pustakawan dan hasil wawancaranya antara lain:

Ibu Hermin memberikan pendapatnya tentang seperti apakah kendala kegiatan penyediaan inormasi yang dihadapi oleh pustakawan, sebagai berikut:

"Kendala yang sering dihadapi oleh pustakawan dalam penyediaan informasi bagi pemustaka itu tidak terlalu banyak, tapi kendala yang paling sering itu adalah banyak pemustaka yang belum tau cara menggunakan komputer dalam kegiatan pengisian data untuk menjadi anggota perpustakaan, dan kendala lainnya adalah masih banyak pustakawan yang melakukan diklat untuk menjadi pustakawan, memang itu adalah masalah yang harus dibenahi oleh perpustakaan ini sendiri, tapi untuk menutupi semua itu perpustakaan selalu memberikan pelatihan kepada para patugas tentang bagaimana menjadi pustakawan yang ideal"'ee. ( wawancara: 21-05-2018).

Selain itu ibu Made juga memberikan pendapatnya tentang seperti apa kendala yang sering dihadapi oleh pustakawan dalam kegiatan layanan.

"Kendala yang kadang kami hadapi disini yang paling sering itu adalah sumber daya manusia, masih banyak petugas yang bukan merupakan pustakawan alih jalur yang tadi nya buka pustakawan yang bisa menjadi pustakawan melalui diklat, termasuk saya. Tetapi perpustakaan selalu memberikan kami pelatihan- pelatihan untuk menjadi seorang pustakawan, dan untungnya kami selalu bisa mengatasi masalah yang ada".(wawancara: 2105-2018).

Sedangkan menurut ibu Devi tentang kendala yang dihadapi oleh pustakawan dalam kegaiatan penyediaan informasi antara lain:

"Pemustaka yang masih gagap teknologi menjadi salah satu faktor utama yang bisa dibilang menghambat, tetapi untungnya pustakawan disini sudah termasuk pustakawan ahli, yang benar-benar kenal dengan teknologi jadi kamin bisa dengan gampang memberikan solusi tentang teknologi yang dihadapi pemustaka, contoh pengisian data saat mendaftar menjadi anggota, masih banyak pengunjung yang tampak bingung-bingung jadi kami harus dengan sigap membantu mereka"'e'. ( wawancara: 21-05-2018).

Dari pernyataan di atas dapat disimpulkan bahwa sumber daya manusia merupakan salah satu faktor yang dapat menghambat dalam kegiatan pelayanan, sumber daya manusia tidak hanya petugas-petugas tetapi juga para pengunjung yang masih belum paham tentang teknologi.

\section{b.Fasilitas}

Fasilitasyang ada si Dinas Perpustakaan dan Kearsipan Provinsi Nusa Tenggara Barat cukup karena memilik berbagai macam fasilitas yang sangat mempermudah pemustaka. Fasilitas yang dimiliki antara lain ruang tunggu 
saan antrian mengisi kartu anggota, computer di ruang internet yang memudahkan pemustaka yang tidak membawa laptop atau hp untuk internet, perpustakaan keliling dan proses pencarian bahan pustaka yang sudah terotomasi dan tentu saja sangat mempermudah pemustaka dalam pencaran informasi. Tetapi fasilitas yang ada masih terbatas karena masih terjadi antrian panjang saat kegiatan pengisian kartu anggota dan di tempat mencetak kartua nggota.

Hal itu diperkuat dengan hasil wawancara yang dlakukan dengan dua orang pustakawan dan satu orang pemustaka. Dan hasil wawancaranya sebagai berikut:

Ibu Hermin memberikan pendapatnya tentang bagaimana peran fasilitas dalam kegiatan penyediaan informasi bagi masyarakat? Dan pendapatnya sebagai berikut:

"Fasilitas adalah salah satu faktor pendukung dan juga bisa menjadi faktor penghambat.Kenapa?Karena fasiltas mampu memberikan kemudahan apabila fasillitas yang dimiliki sudah lengkap dan begitupun sebaliknya.Fasilitas yang kami miliki di sini bisa terbilang lengkap tetapi bisa juga terbilang belum lengkap. Karena masih banya computer yang kurang dan tentu saja akan memperlambat. Contohnya di bagian deposit saja kami hanya memiliki satu komputer dan satu laptop yang digunakan dalam kegiatan penginputan data buku atau entri data, dan tentu saja itu memperlambat kami untuk menyelesaikan kegiatan tersebut dan kami hanya bisa menginput data dalam sehari semampunya $^{\text {ecee }}$.(wawancara: 21-05-2018).

Selain itu untuk memperkuat pernyataan di atas, penulis melakukan wawancara dengan pemustaka yaitu Dian yang merupakan seorang mahasiswa tentang bagaimana pendapat anda tentang fasilitas yang ada di sini? Dan pendapatnya sebagai berikut:

"Fasilitas yang ada di sini sudah bagus dan nyaman, lengkap juga.Hanya saja komputernya mungkin yang kurang jadi kami kadang harus mengantri untuk mencari buku di opacdan juga beberapa rak penitipan barang yang rusak sehingga tidak bisa di kunci selain. "eee(wawancara: 21-05-2018)
Pemustaka yang lain juga memberikan pendapatnya tentang bagaimana pendapanya dengan fasilitas yang ada di Dinas Perpustakaan Dan Kearsipan Provinsi Nusa Tenggara Barat yaitu Ira yang merupakan salah satu pelajar. Dan pendapatnya sebagai berikut:

"Saya senang berada di sini, fasilitas di sini bagus, dan modern.Fasilitas lengkap, cepat dan pasti.Karena mungkin petugas di sini sudah handal.Saran saya sih fasilitasnya lebih ditingkatkan lagi. Apalagi untuk proses pembuatan kartu, pendaftaran anggota baru dan komputer pencarian buku. Kami kadang mengantri lama untuk itu.Itu saja sih, selebihnya sukses selalu".( wawancara: 21-052018)

Dari hasil wawancara di atas dapat disimpulkan bahwa fasilitas dalah salah satu faktor penghambat dan pendukung dalam perpustakaan karena fasilitas yang lebgkap akan memudahkan pemustaka dalam kegiatan pencarian informasi.

\section{E. KESIMPULAN}

Berdasarkan penjelasan dari bab sebelumnya dapat di simpulkan bahwa:

1. Peran perpustakaan dalam menyediakan informasi di dinas perpustakaan dan kearsipan daerah nusa tenggara barat sudah berjalan dengan baik, hal ini dilihat dari jenis koleksi, pelayanan, fasilitas yang ada di dinas perpustakaan dan kearsipan daerah nusa tenggara barat.

Salah satu peran perpustakaan adalah menghimpun informasi meliputi kegiatan mencari, menyeleksi dan mengisi perpustakaan dengan sumber informasi yang memadai dan lengkap baik dalam jumlah, jenis, maupun mutu yang disesuaikan dengan kebijakan organisasi.

2. Faktor pendukung dan penghambat

Yang menjadi faktor pendukung kegiatan penyediaan informasi fasilitas, gedung, peugas perpustakaan dan koleksi.Sedangkan faktor penghambat adalah kurangnya sumberdaya 
manusia berupa pustakawan asli yang berada di perpustakaan tersebut yang masih di gantikan oleh tenaga hasil diklat dan bukan merupakan pustakawan asli dan fasilitas yang kurang sehingga menghambat proses penyediaan informasi.

\section{DAFTAR PUSTAKA}

Suwarno , Wiji . 2011. Perpustakaan \& buku :Wacana Penulisan \& penerbitan . Jogjakarta : Ar - Ruzz Media.

Abdul Kadir. 2002: Pengenalan sistem informasi. Penerbit andi, Yogyakarta.

Anton M, Meliono. 1995: kamus besar Bahasa Indonesia. P.T ellex media komputindo, Jakarta.

http://novanardhi.blogspot.co.id/2012/10/pusta awan-dalam-sebuah perpustakaan

http://download.portalgaruda.org/article.php? rticle $=184146 \& \mathrm{val}=6390 \&$ title $=\mathrm{La}$ yanan\%20dan\%20Pelayanan\%20Perpusta aan\%20:\%20Menjawab\%2oTantangan \%20Era\%20Teknologi\%2oInformasi

http://widodostaff.uns.ac.id diakses pada tgl. 13 September 2014 Jam 11.15 WIB Kamus Besar Bahasa Indonesia.1976.

http://www.sarjanaku.com/2012/11 pengertian-informasi-menurut para- ahli.html?m=1 